Western University Scholarship@Western

Centre for the Economic Analysis of Property Centre for the Economic Analysis of Property

Rights. Economics and Law Workshop Papers

Rights

1983

\title{
Patents, Licensing, and Restrictions on Competition
}

John P. Palmer

Follow this and additional works at: https://ir.lib.uwo.ca/economicsceapr_el_wp

Part of the Economics Commons

Citation of this paper:

Palmer, John P.. "Patents, Licensing, and Restrictions on Competition." Centre for the Economic Analysis of Property Rights. Economics and Law Workshop Papers, 83-10. London, ON: Department of Economics, University of Western Ontario (1983). 
ECONOMICS AND LAW WORKSHOP

83-10

PATENTS, LICENSING, AND RESTRICTIONS ON COMPETITION

by

John P. Palmer*

September 22, 1983

Room: 35 Law School Time: 4:00 p.m.

University of Western Ontario

Major funding for the Centre for Economic Analys is of Property Rights has been provided by the Academic Development Fund, The University of Western Ontario. Additional support has come from The Bureau of Policy Coordination, Consumer and Corporate Affairs. The views expressed by individuals associated with the Centre do not reflect official views of the Centre, The Bureau of Policy Coordination, or The University of Western Ontario.

Subscriptions to the Workshop papers and the Working Paper Series are $\$ 40$ per year for institutions and $\$ 25$ per year for individuals. Individual copies, if available, may be purchased for $\$ 3$ each. Address all correspondence to John Palmer, Centre for Economic Analys is of Property Rights, The University of Western Ontario, London, Ontario, CANADA N6A 5C2. 
FATENTS, LICENSING, AND RESTFICTIONS ON COMFETITION Albstract

by

John F. Falmer*

Fatent systems involve tradeoffs between technological growth and monopolistic restrictions on output. Most of the output restrictions are tolerated by society because we want to encourage inventive and creative activity. The restrictions which we are not willing to tolerate are usually attacked via antitrust or anticombines policies. Competition policy and patent policy confront each other primarily in two areas: cross-licensing and tie-in sales. This paper concentrates on the use of tie-in sales to enhance patentees" profits. The discussion of the many different motives for tie-in sales demonstrates that there is a very strong potential for legal error in attacks on the use of tie-in sales. The facts of a case will often fit either procompetitive or anticompetitive explanations for the use of tie-ins.

Finally, the paper concludes somenthat speculatively that the use of competition policy to attack some of the practices of patentees to increase their profits has in fact bean a wealth-redistributing mechanism which has been used or used successfully primarily against those patentees who have amassed great wealth from their patents. 


\section{The Rationales for Fatent and Other Intel lectual Property Frotection}

It is quite clear that the major justification on efficiency grounds for the creation of intellectual property rights in the 1 aw is to increase the returns for creative activity in order to induce more of it. The concern has typically been that in the absence of institutions to create and protect intellectual property rights, the rest of society has a strong incentive to free ride on inventions and other creations, and, as a consequence, inventors and others would decide to engage in less than the socially optimal or desired amount of their creative activity. One of a number of possible methods used to increase the returns to creative activity has been to grant monopoly rights to creators over their creations and to allow then to exercise these rights themselves, to sell or atherwise transfer the rights, or to 1 icense others to exercise the rights. 1

Of course, the creation of the monopoly rights means that the owners of these rights have an incentive to restrict the production of output using the rights in order to increase their expected profits. This restriction on 
output, ignoring general equilibrium effects, is viewed as socially non-optimal or undesirable by most economists because it leads to too little output in the restricted industry and forces society's scarce resources into less efficient uses in other industries. 2

Herein lies a fundamental conflict: On one hand, ignoring other possible policies, not granting the monopoly right means that there will be too little devotion of resources to creative activitys and on the other hand, granting the monopoly will result in too little production of goods and services which might make use of the creative activity. Speaking more practically, the conflict is between granting the right to earn more monopoly profits and having more inventive activity or granting a lesser right and having a concommitant reduction in inventive activity. Society must choose which form of inefficiency, or more precisely, how much of each form of inefficiency to put up with. There is, presumably, a trade-off here such that if we increase the potential monopoly returns to creators we will induce more creation and more rapid growth, while reducing these returns will provide a disincentive for creation. As will be seen later, however, this presumed trade-off is not always as it seems to be, and the size of the trade-off is always an empirical question which will undoubtedly provoke much guesswork for many years to come. 
Some economists, most notably Flant (1934), Hurt and Shuchman, (1966) and Kitch (1983), have argued that the amount of monopoly created by the patent system is small. They, and Burstein (1960a,b) to some extent, have emphasized that there are many substitutes available for patented products and processes, especially in the long run. The availability of substitutes 1 imits the potential market power of patentees and hence limits the allocative distortions of the patent system. If their argument has empirical substance, it also means that the patent system creates very 1 ittle incentive for creative activity since it does little to enhance the returns to the activity. Following this line of argument, the benefits of having a patent systen are 1 ikely to be small, but so are the social costs due to monopolistic distortion of resource allocation; indeed, these authors might have argued that the major impact of the patent system is to create administrative costs and thereby to generate net social costs.

Other writers, most recently among them Scherer $(1980,1983 a, b)$, have argued that the monopoly distortions created by the patent system are potentially very large because the substitutes available for many inventions are quite poor. As I have said, though, it must be kept in mind that the arguments between these two schools of thought are basically about imprecise empirical magnitudes. While they 
are fascinating displays of the authors" rhetorical skills, they shed little light on the magnitudes involved. Unfortunately the actual size of the monopoly distortion or the creativity incentive engendered by the patent system cor intellectual property legislation in general) must remain a mystery for some time yet. Several recent attempts by such wel 1-known scholars as Cheung (1983), Hall (1983), McFetridge (1983), and Scherer (1983a) have not given us the kinds of answers we might like. Hence this paper must concentrate on smaller, more marginal concepts.

Although we do not know the size of the elasticity of patent activity with respect to the amount of market power granted by the patent system, most economists assume that this elasticity is positive: we assume that more market power attached to patents will generate more of the types of activities which are likely to lead to patentable inventions. Consequently, revisions of the patent system, whether legislatively or judicially initiated, will likely affect both the amount of competition in the marketplace and the incentive for creative activity. Similarly, policies which affect restrictions on comnpetition may also affect the amount of inventive activity which society will get. If firms in general find it more difficult to earn profits due to any type of government policy, including antitrust or anticombines legislation, we should expect there to be less of an incentive for people to do anything to earn profits 
(abstracting from the wealth effect), including inventing.

\section{Patents and Competition Policy}

The interaction between patent 1 aw and antitrust is double-faceted. One face of the relationship involves attempts, sometimes masterfully disguised, to do no more than to whittle away at the returns of a patent monopoly. The policies proposed under this facet of the relationship are, in effect, a wealth-redistributing and highly graduated progressive tax on the returns of patentees. The other face of the relationship involves concern that the patent monopoly can lead to other anti-competitive behaviour. of course the two faces are related. Attacking alleged anti-competitive behaviour of patentees will also have the effect of reducing their returns.

Many of the conflicts between patent 1 aw and antitrust law have arisen because of the terms of patent licences. Al though there are several cost-reducing and/or pro-competitive reasons for the existence of 1 icensing schemes, there are some other motivations for their existence which can be thought of as anti-competitive. As Burstein (1960b) has pointed out in his classic article on ful1-line forcing, a firm which has some market power would generally like to do more than simply charge the monopoly price for its output; it can usually increase its return by 
capturing some of the consumer surplus of its customers. Making a tied sale be one of the conditions of the licence or of the sale may be one way to do this. In addition, patentees of inventions which are substitutes for each other may engage in cross-licensing of their patents. They might do so to reduce the costs of 1 itigation about patent validity, and/or to form a cartel and enhance their monopoly returns.

The potential problems of distinguishing cost-saving as a motive for cross licensing from the cartel motive have been admirably discussed by George Priest (1977). The only point I would like to add to his discussion is that the possibility of legal error may reduce the incentive to engage in inventive activity. 3 To see this point, suppose first that a cross licensing arrangement is drawn up between two firms to do nothing more than blatantly form a cartel. If they are found innocent of vialating antitrust 1 aws, the signal is given that formation of cartels in this fashion has a less than sure chance of being detected and punished; the expected costs of forming cartels this way will diminish; and there will be an increased incentive for firms to engage in this behavior.

Suppose, alternatively, that the firms have established a cross licensing agreement only to reduce costs, whether they are costs of production or costs of litigation. If they 
are found guilty of an antitrust violation anyway, then the expected benefits of legal bevaviour will have diminished, creating even more incentives to form cartels through cross licensing agreements. Fegardless of the type of legal error, creative and inventive activities become relatively less well rewarded as the amount of these types of legal error increases.

Legal error in these two situations can be thought of as analogous to Type I and Type II errors in statistical inference. Finding the innocent guilty can be thought of as a Type I error, and finding the guilty innocent as a Type II error: and as with most statistical tests, reducing the amount of one type of error will necessitate increasing the amount of the other, especially given a constant expenditure ont the reduction of errors. In the case of patents and antitrust, declaring most cross licensing agreements to be legal would greatly reduce the Type I errors but greatly increase the Type II errors, creating an incentive for the formation of more cartels using cross licensing as their vehicle. Similarly, declaring most of them illegal would decrease the incentive for firms to reduce costs in this fashion. 


\section{Tie-in Sales}

Aside from cartel formation via cross licensing, the other major alleged anticampetitive effect resulting from unfettered implementation of the patent monopoly involves the use of tie-in sales. It has been asserted that tie-in sales can be and have been used to restrict competition in two ways: first, it is claimed that the patent monopoly is sometimes extended beyond the market for the tying good (which is patented) to the tied good market (which is usually more nearly competitive); second, and related, it is claimed that the patent monopoly is sometimes used along with tie-in sales to create a barrier to entry into the combined market of the tying and tied goods or services. Despite the fact that these two arguments have been fairly successfully attacked during the past decade or two, there remains an element of truth in each of them.

We know that the extension of market power argument is meaningless in the instance of tie-in sales involving goods used in fixed proportions.4 If $X$ and $Y$ are used together in fixed proportions, it doesn't matter what the price of either $X$ or $Y$ is: potential purchasers will be concerned only about the combined price of $X$ and $Y$. If a patentee of $X$ will sell it only if the customer agrees to purchase $Y$ from him or her as well, it does not matter whether the patentee extracts the monopoly profits accruing to the 
patent on $X$ from the actual sale of $X$ or from the sale of $X$ and $Y$ together. In fact $X$ could be given away and the entire profits extracted from the sale of $Y$, or $Y$ could be given away and the entire profits extracted from the sale of $x$. The point is that if the patentee is a profit maximizing firm, he or she will be able to earn the maximum potential profits from $X$ alone, and a tie-in with $Y$ will be unnecessary. Furthermore, the tie-in cannot add even a penny to the profits of the patentee since raising the price of $Y$ would then raise the joint price of $X$ and $Y$ together above the profit-maximizing price.

The case of variable proportions is different. 5 If $X$ and $Y$ need not be used together in a precise combination, there may be some substitution possibilities between the two of them or between either or both of them and some other products. In any of these cases, if the patentee tries to charge only the profit-maximizing price for $x$ without restricting the choice of the purchaser, he or she will lose some potential profits as the purchaser substitutes away from the patented product. As Burstein has demonstrated so ably, the patentee has an incentive in these cases to implement tie-in sales to reduce the substitution possibilities available to the purchaser (or licensee) and hence to increase the expected return to the patent. In a way, one could call this behavior extension of market power. Doing so, however, ignores the motive for it. Once 
the motive is clearly recognized, we realize that we are right back to the original choice discussed in the first section of how much market power and how large a monopoly return should be made availabe to patentees to encourage inventive activity.

The second form of alleged anticompetitive result of tie-in sales is the creation of increased barriers to entry. When one considers that the patent monopoly by itself creates a potentially large barrier to entry, it becomes less clear how much of an additional anticompetitive effect could be caused by the addition of a tie-in sale to the patent. One possibility might be that there could be competing patents for a particular operation: if the first or largest patentee decides to bundle his or her product with some tied goods, others may feel obliged to do likewise lalthough unbundling may be an equally attractive marketing strategy). If bundling requires additional financial capital, and if the financial capital markets have some imperfections, then the existence of a tie-in sale may tend to create a somewhat higher barrier to entry. However, when information costs and risks are taken into consideration, it is difficult to establish that the financial marlets have any measurable imperfections. Hence the barrier-to-entry argument cannot be taken very seriously.6

\section{Other Reasons for Tie-in Sales}


Probably the most important reason that we observe tie-in sales as a condition for a licence to use a patent is that there are economies of joint sales. Automobile engines and chassis are sold together primarily because doing so dramatically reduces transactions and transportation costs. Similarly for pencils and erasers. In less trivial situations, this explanation is still valid to the extent that patentees and their customers can reduce their costs by transacting for more rather than fewer of the customers" requirements at one time. Negotiation costs, administrative costs and shipping costs may all be reduced. It is unlikely that society would wish to impede such attempts to use scarce resources more efficiently, as in these situations. Allowing tie-in sales when there are economies of joint sales would be efficient in the absence of any other effects, and the potential increase in profits would provide an additional incentive for creators to engage in inventive activity. Only if one believes that there is too much of an incentive to engage in inventive activity would one be able to argue on efficiency grounds that these tie-in sales should be prohibited, but it seems likely that reducing the reward to a patentee could be done, if desirable, in some other, more efficient manner.

Another reason that firms engage in tie-in sales is to evade price controls. In this category, we can observe that 
if the price of gasoline is set below the market-clearing price, customers are somewhat unsubtly encouraged to purchase fan belts, tune-ups, or even lucky rabbit feet at comparatively high prices along with their gasoline. Whether such tie-ins should be viewed as anticompetitive depends in part on one's view of how much people should be allowed (i.e. encouraged) to circumvent the price contrals; such circumvention is sure to be viewed by some as procampetitive.

Sometimes, it has been argued, tie-in sales have been used to police a cartel and can have concomitant anticompetitive effects. An important example suggested by Cummings and Fuhter (1979) involved Northern Facific, which leased land along its right-of-way subject to the tying condition that the lessee ship with Northern Facific or allow it the opportunity to match a lower freight rate offered by a competitor. Because freight rates were set above the competitive level by the Interstate Commerce Commission, this tie-in sale gave Northern Facific the opportunity to determine whether any of its competitors were violating the ICC rate regulations and enabled Northern Pacific, along with the ICC, to enforce the cartel-type freight rates. To the extent that patentees might be able to incorporate similar tie-in clauses into their licences, the tie-in sales could be viewed as anticompetitive. 
In direct opposition to the cartel enforcement

explanation of tie-in sales is an explanation suggesting that tie-ins can be used to facilitate cheating which would be difficult to detect within a cartel. Suppose, as has been suggested in Peterman's (1979) study of the International Salt Case, that a salt producer were a member of a salt-selling cartel. It would like to increase its profits by selling more salt, even if it had to lower its price of salt just a bit. Unfortunately for it, however, it cannot lower its price of salt because doing so would invite a retaliatory price war from the other members of the cartel. It can accomplish the same thing, though, by renting its patented machine to mix salt and water at a relatively low rental rate and requiring the lessees to purchase all of their salt requirements from it at the cartel price. This tie-in sale will effectively reduce the price of the salt to the users without necessarily setting off a price war within the cartel. The mixing machine must be rented, though, and not sold or else the user will have an incentive to purchase the low-priced machine and then not necessarily purchase salt from the patentee; the price of salt and the machine combined will have been lowered for the customer but will not have as certain an impact on the sales of salt by the patentee since the customer might now purchase salt from a different member of the cartel.

Notice the similarity between the last two cases, ane 
involving cartel policing and the other involving cartel cheating. In both cases the possible cartel was in the industry of the tied good, not the tying good as was often argued in cases involving extension of market power or creation of barriers to entry. In both cases, the tying good was rented or leased, rather than sold, in order to allow continued enforcement of the tie. In both cases, the firm was willing to meet competitors' prices of the tied good. In fact, the cases are so similar that the facts of each could be used to support the opposite argument!

Suppose that Northern Pacific had wanted to cheat on the ICC-sanctioned cartel. An effective way for them to do this would have been to lease land along their right of way for less than the market rental rate but to have required that the lessees do all their shipping with Northern Pacific. Effectively the freight rates would have been lowered, but not in an obvious way which would have attracted the wrath of the ICC, or at least not immediately. They would still, under this very different scenario, be willing to match the freight rates offered by competitors in an attempt to make the tied lease packages more attractive to potential lessees. Suppose, too, that International Salt had wished to be a member of a salt cartel and had also wanted to devise a way to detect whether its compatriots were cheating on the agreed upon price for salt. In this case, it could have offered to rent its mixing machines 
along with a tie-in sale of salt as described earlier, but now the offer to meet any competitor's price for salt becomes a mechanism for transmitting information to the firm about who is selling salt below the cartel price.

clearly, the only way to distinguish between the two conflicting explanations for these tie-in sales is to examine carefully the prices of the tying goods relative to the market prices of these products. If Northern Facific was leasing its 1 and for rental rates commensurate with the rents of other similarly situated land, it is extremely unlikely that cheating on the ICC freight rates was the motive for the tie-in clause in the leases. Alternatively, though, if their rental rates were below the market rate, a prima facie case that they were underpricing the cartel would not be established since they might be willing to forego some rental receipts in order to acquire more information about their competitors" pricing practices.

The problems of distinguishing between the motivations for tie-in sales become even more difficult when there is not an existing market of clearly comparable substitutes for the tying good. Suppose there are a number of different patented salt brine mixing machines on the market, each with some advantages and some disadvantages in comparison with each other. How, then, is one to determine whether any particular one of them is being sold at a discount in order 
indirectly to lower the price of salt? Hedonic price indices might be of some help except that they would be estimated using perhaps distorted price data for the machines initially. In general the answer has to be that for most patented products which are used as the tying good, it is impossible to determine whether the tie-in sale is a manifestation of procompetitive or anticompetitive behavior. Because the possibility of either type of legal error is so large in these situations, and because legal error can seriously distort incentives, it seems reasonable to look to other criteria and other motivations for tie-in sales if they are to be dealt with explicitly by competition policy. It turns out, though, that looking at other motivations finds that they, too, are consistent with the facts of these cases. It proves to be virtually impossible with any reasonable amount resources to determine which of the many motivations was at work in each case.

\section{Protection of Good Will, Price Discrimination, and}

\section{Risk Reduction}

So far six different motives for patentees to engage in tie-in sales have been examined: (1) extension of market power, (2) creation of barriers to entry, (3) economies of joint sales, (4) evasion of price controls, (5) policing a cartel, and (6) cheating on a cartel. This section presents three more reasons that firms might try to implement tie-in 
sale arrangements: (7) the protection of good will, (8) metering and price discrimination, and (9) the allocation of risk.

The protection-of-good-will argument is invoked frequently when tie-in sales involve patented goods or pracesses. The patented product is viewed by its producer (and many consumers) as being sufficiently novel or complex or exacting that certain imprecisely defined yet quite demanding standards must be met in the products which are used in conjunction with it. The patentee knows that the tied good which it sells works well with its patented product (the tying good), and rather than attempt to specify the requisite standards to be met by other producers for the tied good, the patentee simply implements a tie-in sale. Classic cases have involved service contracts tied to community antenna systems and glass-lined silos tied to spiral silage unloaders.7 A less successful, but equally classic use of this argument involved punchcards tied to tabulating machines. 8 The uses and misuses of this argument suggest that while it probably has validity in circumstances invalving high information costs or complemetary patents, it is also susceptible to being invoked in many situations in which other motives underlie the implementation of a tie-in sale.

One of the most popular explanations for the existence 
of tie-in sales is the use of the tied good as a metering device to facilitate price discrimination.9 Customers who use a patented invention more, the argument goes, will generally have a less elastic demand for it. If that is the case, leasing them the patented product (e.g. a salt brine mixing machine) and charging a supracompetitive price for the tied product (salt) will effectively charge the heavy users a higher price for the patented machine, thus extracting more consumer surplus from them. Burstein (1960b) was skeptical of this argument more than two decades ago and for good reason. Much of what might appear to be raising the price to heavy users above the price charged to 1 ight users is, in reality, nothing more than increasing the price-cost margin for the heavy user to bring it up to that of the lighter user; it is, in fact, the reduction of unprofitable price discrimination in favor of the heavier users, not the imposition of price discrimination on them.

In his recent discussion of price discrimination and tie-in sales, Liebowitz (1983) shows that if a patented machine is rented by the week or month or some other specified period of time but wears out according to how heavily it is used, the heavy users will impose greater costs per use of the machine on the patentee. To charge these heavier users a higher rental fee according to their use of the machine may involve substantial metering costs unless a tie-in sale can be used instead. Charging the heavy 
users more and bringing their effective price in line with the costs they impose on the patentee can be effected via a tie-in clause in the rental agreement which specifies that a complementary tied good (e.g. salt) must be purchased from the lessor/patentee at some specified price which is above the price for similar goods available from other manufacturers. As Liebowitz argues, it is difficult to call this price discrimination when in fact it is a process which removes unprofitable price discrimination. Regardless of what it is called, though, it has the same effect, namely, it changes the prices charged to different customers. In addition, this metering/price discrimination argument is inconsistent with the facts of some cases, such as the International Salt case, because it requires that the patentee charge more than the competitive price for its tied good, whereas International Salt specifically agreed to charge no more than the market price for its tied good $(s a l t)$.

As an alternative to the above propositions, Burstein and Liebowitz (in a somewhat more formal presentation of the material) have suggested that tie-in sales may be used as a risk allocation mechanism. Since the comparatively new discipline of economic analysis of common law has begun to place considerable emphasis on the question of who is the least-cost bearer of risk in contracts, property, and torts, it seems 1 ikely that similar analysis would be of use in an 
attempt to understand tie-in sales. 10

A 1 icensee of a patent faces a number of risks about which neither he or she nor the patentee can do anything. One risk faced by the licensee can, however, be insured against by the patentee at a relatively low cost. This is the risk of how well the 1 icensee will do in the industry relative to other licensees, referred to by Liebowitz as market share risk. Each individual licensee faces market share risk, but the total amount of market share risk among all of the 1 icensees is near zero since their market shares probably will add up to about the same total regardless of how they are distributed among them. The patentee/1icensor can internalize this risk: by using tia-in sales to, in essence, provide insurance to the 1 icensees.

The means of providing this insurance works as follows: the patentee could sell machines embodying the patent (e.g. salt brine mixing machines), but potential purchasers (e.g. canneries) are concerned that they might become locked into large fixed costs and then not do very well in their own markets (for canned fruits or vegetables). The patentee (International Salt) can ease this concern by leasing or renting them the machines, hence reducing their fixed costs. The concern can be eased even further if the rental rate for the machine is set below costs and the difference is made up by charging the lessee a higher price for a tied good 
(salt). For example, a salt brine mixer or a tabulating machine could be rented for a nominal sum and the lessee could be charged more for salt or punchcards. In this way, if the lessee's business does well, the patentee will share the benefits, and if the lessee's business does poorly, the patentee will share in the losses. Because the benefits and losses will net out across all the lessees, the patentee will be assuming very little additional risk while reducing the amount of risk faced by each of the lessees. The tie-in sale in this case becomes a relatively low-cost way of selling market share insurance along with the services of the patented machine. It is economically efficient and, by itself, it is likely to have no anticompetitive effects. As with the metering explanation, this explanation does not seem consistent with tie-in clauses agreeing to meet the market prices of the the tied good. Nevertheless, in this section, as in the previous one, different explanations have been presented for the same set of facts; and more importantly, these different explanations have pro- and anti-competitive effects which cannot be separated.

\section{Patents and Competition: Reprise}

We now have at least nine explanations available for tie-in sales. Others are sure to be developed in the future. As has already been shown, it is extremely difficult to distinguish between some of the competing explanations. The 
facts of any particular case may be consistent with several of the different and perhaps mutually exclusive explanations, some of which are anticompetitive and some of which are procompetitive.

Similarly with cross-1icensing of patents, the distinctions between the different cases are quite prone to error. The result is that al though most people "know" deep in their bones that sometimes patents give rise to undesired behavior, this knowledge cannot be systematized for any practical use.

Because these different explanations cannot easily, if at all, be distinguished from each other, one sees several of them in different forms applied by different sides in each case, and one also sees the courts making what appear to be arbitrary decisions involving patents and competition policy. It is certainly difficult to put forward a persuasive case that the decisions have been made on either pro- or anticompetitive grounds.

Indeed, the best predictor of the courts" reactions to these cases may follow something along the lines of an infant industry argument: it is acceptable to earn supranormal profits in the early stages of working the patent, but beyond that, what might be viewed as anticompetitive behavior will be. While there are cases 
consistent with this theory, 11 there are others which do not appear to support it.12 Nevertheless, it does seem that the U.S. courts have been more likely to find against a patentee if the patent has been extremely profitable. This theory might help to explain why the courts have looked askance at patent 1 icences which require the payment of royalties after the patent has expired. Even though such licences are most 1 ikely nothing more than insurance schemes like those described in the previous section or indirect ways of granting loans from the patentee to the licensee, they have typically been decried as anticompetitive by the courts land the 1 icensees, but only after the patent has expired).

If in fact the redistribution of the wealth accruing to patent holders is desired by society, selective interpretation of the antitrust and anticombines 1 aws may be one way to manifest such a goal. It may be thought (and possibly even correctly sol that a high marginal tax rate imposed on the returns to very profitable patents would have a negligible impact on inventive activity and would at the same time have socially desirable distributive and efficiency effects. Implementing such a tax scheme may be difficult politically or administratively, whereas use of competition policy to accomplish the same goals may prove much easier. The problem, of course, is that selective and somewhat arbitrary application of competition policy to 
cases involving patents, in addition to weakening the payoff to inventive activity, also weakens the effectiveness of competition policy. While such a result may have much to recommend it, that is a topic for a different study. 


\section{FOOTNOTES}

*Associate Professor of Economics and Director of the Centre for Economic Analysis of Property Rights, The University of Western Ontario. Helpful suggestions from Michael McKee and Michael Trebilcack are gratefully acknowledged. It will be quite apparent to the reader that I owe an intellectual debt to Meyer Burstein and to Lester Telser, and hence by derivation to Aaron Director and to Adam Smith.

1. One of the best treatments of the economic rationales for legal intellectual property protection is presented in an unfortunately somewhat obscure monograph by Hindley (1971). Other discussions are provided in Demsetz (1967), Palmer (1982), and Ladas (1930).

2. See the Report on Intel lectual and Industrial

Property from the Economic Council of Canada (1971) for a good example of these views.

3. This discussion is an application of the analysis of legal error presented by fosner in his text (1977).

4. One of the better discussions of tie-in sales involving goods used in fixed proportions is provided by Posner (1974).

5. See Burstein (1960b)

6. Despite much recent work done on financial capital markets incorporating information costs (see Demsetz, 1974), for some inexplicable reason, some scholars still place some credence in the argument that tie-in sales can create 
substantial barriers to entry. See, e.g., Scherer (1980).

7. U.S. V. Jerrold Electronics Corp. (E.D. Pa. 1960); and Dehydrating Process Co. V. A.0. Smith (1 Cir. 1961).

B. I.B.M. V. U.S. (S.C. 1936).

9. Although it has often been repeated, the first major statement of the price discrimination argument was presented by Bowman (1957). According to oral tradition, the concept was first devised either by Aristotle or Aaron Director. 10. Earlier, though somewhat different, versions of this argument were made by Burstein (1960a) and Stigler $(1968)$.

11. U.S. V. Jerrald Electronics Corp. (E.D. Pa. 1960); Kobe v. Dempsey Pump Co. (10 Cir. 1952); Fortner Enterprises Inc. V. U.S. Steel (S.C. 1969); and U.S. V. Loew's Inc. (5.C. 1962) are some of the cases consistent with this view. Jerrold, is perhaps the best example of a court's use of the infant-industry/wealth redistribution criterion for deciding a case.

12. See U.S. V. General Electric Co. (S.C. 1926); However G.E. was successfully attacked in a later case involving patents and antitrust in U.S. V. General Electric Co. (S.D.N.Y. 1948). This use of a few cases to establish an argument is probably not particularly strong. However, when one recalls that wealth redistribution seemed important to many members of the U.S. Supreme court in the mid-twentieth century, these cases help to lend at least a little credibility to the hypothesis. 


\section{FEFERENCES}

Bowman, W.S.Jr., "Tying Arrangements and the Leverage

Problem," Yale Law Jour., Nov. 1957.

Burstein, M.L., "The Economics of Tie-in Sales,"

R.E.Stat., 1960.

, "A Theory of Full-Line Forcing,"

\section{Northwestern Law Review, 1960.}

Cheung, 5.N.S., "Property Fights and Invention," presented

at The Economics of Intellectual Property, a

conference sponsored by The Centre for Econamic

Analysis of Property Fights, London, Ontario, 1983.

Cummings, F.J., and Ruhter, W.E., "The Northern Pacific

Case," Jour. of Law and Econ., Oct. 1979.

Demsetz, H., "Toward a Theory of Froperty Rights,"

American Economic Review, May, 1967.

, "Two Systems of Belief About Monopoly," in

Goldschmid, H.J., Mann, H.M., and Weston, J.F.,

Industrial Concentration: The New Learning,

Toronta, Little Brown, 1974.

Economic Council of Canada, Report on Intel lectual and

Industrial Property., Ottawa, 1971.

Hall, C.D., "Fatents, Licensing, and Antitrust," presented

at The Economics of Intellectual Property, a conference sponsored by The Centre for Economic Analysis of

Property Rights, London, Ontaria, 1983.

Hindley, B.V. The Economic Theory of Patents, Copyrights, and Reqistered Industrial Designs. Queen's Frinter, 
Dttawa, Economic Council of Canada, 1971.

Hurt, R.M. and Schuchman, R.M., "The Economic Rationale of Copyright," American Economic Fieview, May 1966.

Kitch, E.W., "Patents and Market Power," presented at The Economics of Intel lectual Property, a. conference sponsored by The Centre for Econamic Analysis of Property Rights, London, Ontario, 1983.

Liebowitz, S.J., "Tie-in Sales and Price Discrimination," Econ. Inquiry, 1983 (forthcoming).

Ladas, S.P., The International Protection of Industrial Property, Cambridge, Mass., Harvard Press, 1930. McFetridge, D.G. and Fafiquzzaman, M., "The Scope and Duration of the Patent Right and the Nature of Research Rivalry," presented at The Economics of Intellectual Property, a conference sponsored by The Centre for Economic Analysis of Froperty Rights, London, Ontario, 1983.

Palmer, J.F. with Resendes, R.R., Copyright and the Computer, Ottawa, Consumer and Corporate Affairs Canada, 1982.

Peterman, J.L., "The International Salt Case," Jour. of Law and Econ., Dct. 1979.

Plant, A., "The Economic Aspects of Copyright in Books," Economica, 1934. " "The Economic Theory Concerning Patents for Invention," Economicam 1934. Posner, R.A., Antitrust Cases, Economic Notes, and Other 
Materials, Toronto, Little Brown, 1974. , Economic Analysis of Law (2d ed),

Toronto, Little Brown, 1977.

Priest, G.L., "Cartels and Patent License Arrangements,"

Jour. of Law and Econ., Det. 1977.

Scherer, F.M., "Discussion," (unpublished) presented at The

Econamics of Intellectual Property, a conference

sponsored by the Centre for Economic Analysis of

Property Rights, London, Ontario, 1983.

- Industrial Market Structure and Economic

Performance, Chicago, Rand McNally, 1980.

, "The Propensity to Patent," Int. J1. of

Industrial Orq., March, 1983.

Stigler, G.J., "A Note on Block Booking," reprinted in

The Orqanization of Industry, Homewood, I11.,

Irwin, 1968. 